\title{
Pocas “palabras mágicas” y demasiadas “trágicas”
}

\section{Few 'magic words' and too many 'tragic' words}

\author{
Pronunciada primero, \\ luego escrita, \\ la palabra pasó de boca en boca, \\ siguió de mano en mano, \\ de cera en pergamino, \\ de papel en papel... \\ Ángel González, La palabra ${ }^{1}$
}

Nos gustaría observar cuidadosamente las palabras que cualquier persona puede decir en algún momento, y así poder notar y hacer notar tanto las que son impropias y trágicas como las que son mágicas y facilitadoras. Partimos de un principio: es importante medir las palabras, hablar con cuidado, con la idea de no generar conflictos ni distancia con las palabras que ponemos en una conversación.

Empecemos a "palabrear". Palabra es la representación gráfica de la palabra hablada; es el empeño que hace alguien de su fe; es el dicho, razón, sentencia, parábola ${ }^{2}$... Palabras encontramos buenas y malas, mágicas y trágicas, facilitadoras y dificultadoras.

La palabra fue dicha para siempre...

La elijo entre otras muchas

La empaño con mi aliento

y la lanzo

pájaro o piedra ${ }^{1}$.

Empezamos por las primeras, las buenas: expresiones dichas con intención de agradar y convencer; palabras clave, las más significativas de un texto. Todas ellas se podrían nombrar como palabras "mágicas", que son algo más que la voz que usan los magos; son palabras que nos pueden servir para alcanzar metas. Son las palabras como solución: bueno, mejor, fácil, eficaz, seguro; son palabras que, al oírlas, nos dicen cosas positivas, facilitan la comunicación, abren al acuerdo.

Por otra parte, a veces nos gustaría que la gente omitiera alguna palabra. Hay personas a quienes en ocasiones se les escapa una palabra al proferir, por descuido, una expresión disonante o molesta. Son las palabras "trágicas": al utilizarlas pueden hacer -hacen- daño a la persona receptora. Son a veces palabras gruesas, mayores, injuriosas, que hieren a quien las recibe; son ofensivas. Son como los virus y las bacterias, que producen infecciones y, por tanto, dolor, enrojecimiento, inflamación; infectan la relación entre personas. Las llamamos virus y bacterias de la comunicación. Existen tres "virus" y cinco "bacterias" a erradicar (o disminuir) de nuestras bocas. Los tres virus son: acusaciones, amenazas y exigencias. Las cinco bacterias son: juicios, menosprecios, sarcasmo e ironía, etiquetas y generalizaciones.

Veamos dos ejemplos. Primero, en una viñeta de Ricardo y Nacho sobre la epidemia de meningitis de finales de los años 1990 se decía «Sanidad aclara que no debe cundir el pánico porque no es una epidemia, los casos de meningitis son los habituales y las muertes algo excepcional»; al final lo que quedaba en la gente eran palabras trágicas como «epidemia», «meningitis», «pánico», «peligro». Segundo, cuando vimos al ministro de sanidad del momento que decía: «No estamos en una situación de alarma ni de especial gravedad» ${ }^{3}$; he ahí dos palabras trágicas - «alarma» y «gravedad» - que pueden producir miedo en vez de tranquilidad en la persona que las recibe.

Debemos buscar palabras facilitadoras, llenas de verbos en condicional, de refuerzos de lo importante, de expresiones en plural, de declarar deseos, de preguntar (preguntar y preguntar), de pedir opinión, de explicar el porqué y para qué de las cosas...

A veces, las palabras se posan sobre las cosas,

como una mariposa sobre una flor,

y las recubren de colores nuevos ${ }^{1}$.

Palabras en búsqueda del encuentro, de la confianza, del diálogo, de la transparencia, de la cercanía; de la comunicación.

\section{Bibliografía}

1. González A. Palabra sobre palabra. Obra completa (1956-2001). Barcelona: Seix Barral; 2004

2. Real Academia Española. Diccionario de la lengua española. Vigésimo segunda edición. Madrid: Real Academia Española; 2001.

3. La epidemia del miedo. DVD: Madrid; marzo, 1997.

Joan Carles March Cerdà * y María Ángeles Prieto Rodríguez Escuela Andaluza de Salud Pública, Granada, España

*Autor para correspondencia. Correo electrónico: joancarles.march.easp@juntadeandalucia.es (J.C. March Cerdà). 